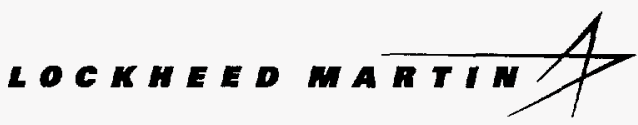

ENVIRONMENTAL

RESTORATION

PROGRAM

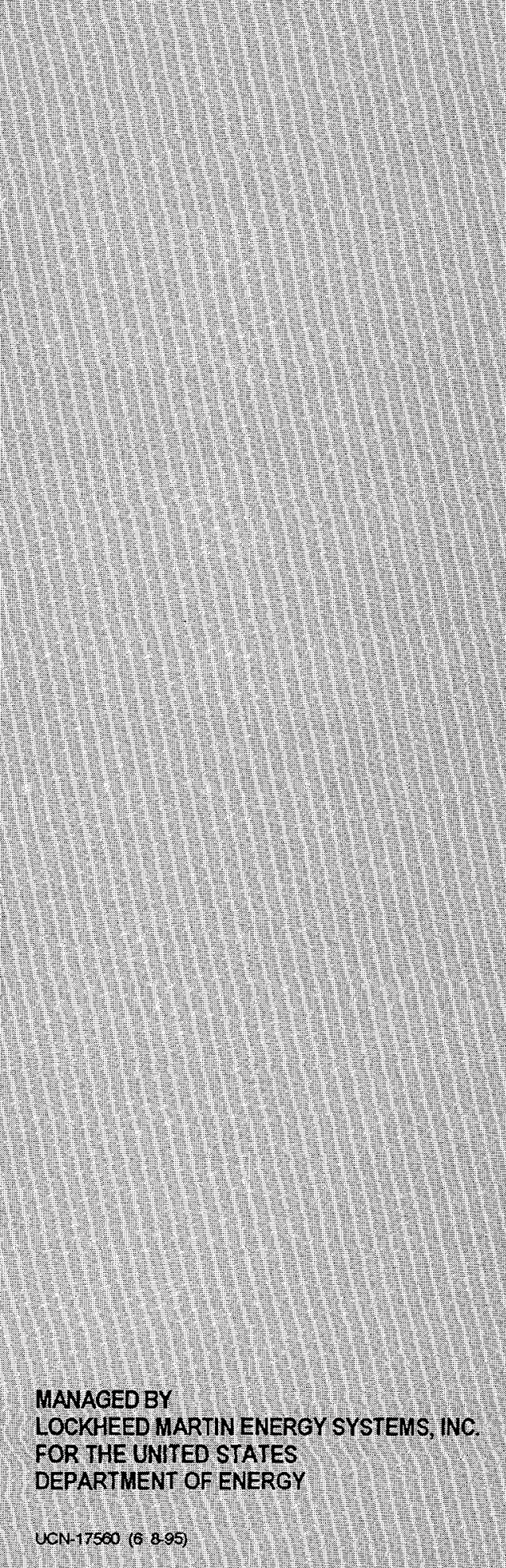

\section{Limiting Conditions Document for the Oak Ridge Research Reactor (ORR), Oak Ridge National Laboratory, Oak Ridge, Tennessee}
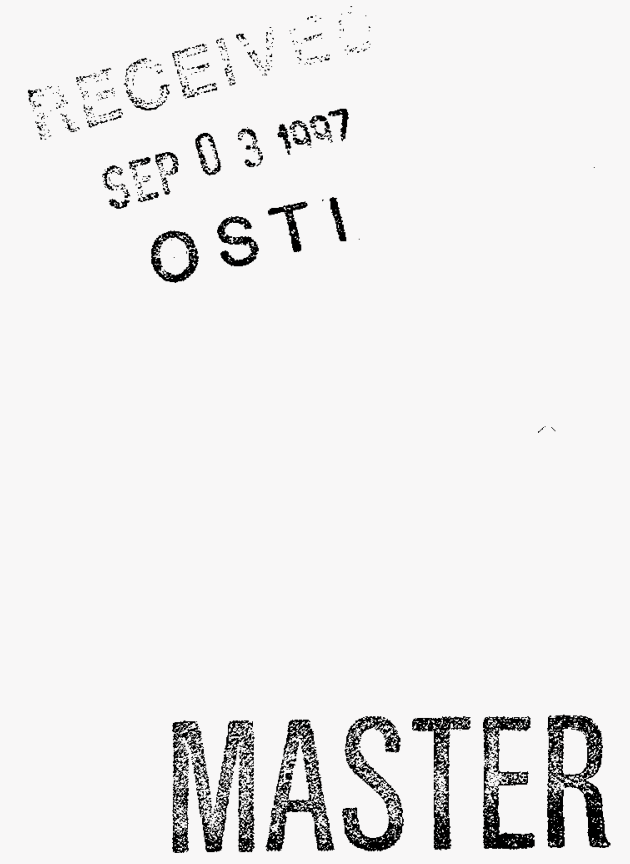

This document has been approved by the ORNL Technical Information Office for release to the public. Date: $8 / 28797$ 


\title{
Limiting Conditions Document for the Oak Ridge Research Reactor (ORR), Oak Ridge National Laboratory, Oak Ridge, Tennessee
}

Date Issued-August 1997

\author{
Prepared for the \\ U.S. Department of Energy \\ Office of Environmental Management \\ under budget and reporting code EW 20 \\ Environmental Management Activities at \\ OAK RIDGE NATIONAL LABORATORY \\ Oak Ridge, Tennessee 37831 \\ managed by \\ LOCKHEED MARTIN ENERGY SYSTEMS, INC. \\ for the \\ U.S. DEPARTMENT OF ENERGY \\ under contract DE-AC05-84OR21400
}




\author{
APPROVALS \\ Limiting Conditions Document \\ for the Oak Ridge Research Reactor \\ (ORR), Oak Ridge National Laboratory, \\ Oak Ridge, Tennessee
}

ORNL/ER-405

August 1997

Recommended by:

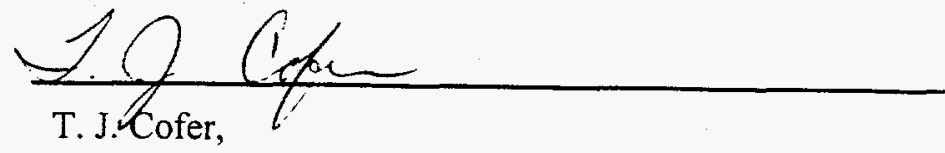

Facility Manager

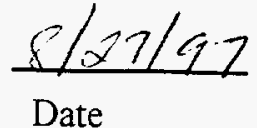

Approved by:

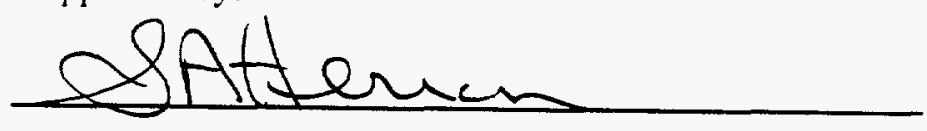

S. A. Herron

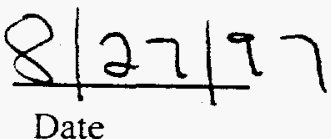

Manager, ORNL Surveillance and Maintenance Program

Date

\title{
DISCLAIMER
}

This report was prepared as an account of work sponsored by an agency of the United States Government. Neither the United States Government nor any agency thereof, nor any of their employees, makes any warranty, express or implied, or assumes any legal liability or responsibility for the accuracy, completeness, or usefulness of any information, apparatus, product, or process disclosed, or represents that its use would not infringe privately owned rights. Reference herein to any specific commercial product, process, or service by trade name, trademark, manufacturer, or otherwise does not necessarily constitute or imply its endorsement, recommendation, or favoring by the United States Government or any agency thereof. The views and opinions of authors expressed herein do not necessarily state or reflect those of the United States Government or any agency thereof. 


\section{DISCLAMMER}

Portions of this document may be illegible in electronic image products. Images are produced from the best available original document. 


\section{PREFACE}

Limiting Conditions Document for the Oak Ridge Research Reactor (ORR), Oak Ridge National Laboratory, Oak Ridge, Tennessee (ORNL/ER-405) defines the limitations, surveillances, and administrative guidelines necessary to ensure safe conditions at the Oak Ridge Research Reactor. This document was written under Work Breakdown Structure 1.4.12.6.2.01.01 (Activity Data Sheet 3701). 


\section{CONTENTS}

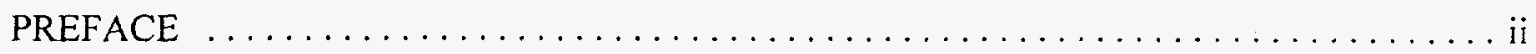

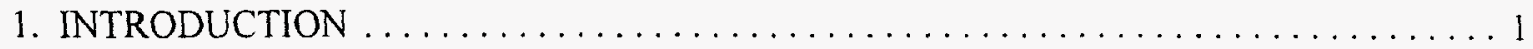

2. LIMITING CONDITIONS FOR OPERATIONS $\ldots \ldots \ldots \ldots \ldots \ldots \ldots \ldots \ldots \ldots$

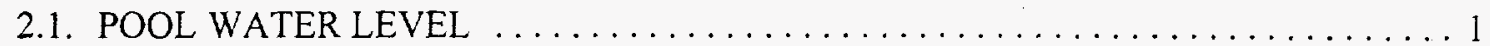

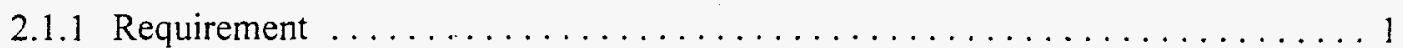

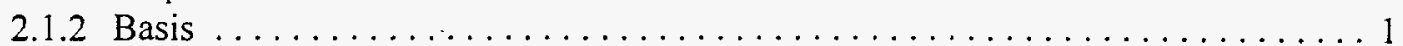

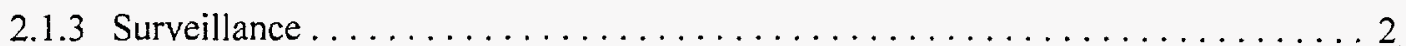

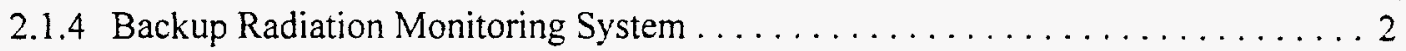

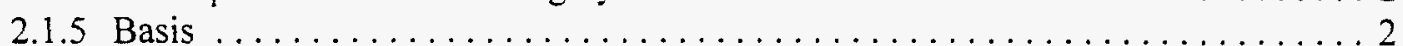

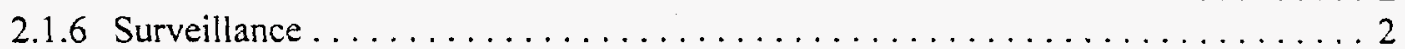

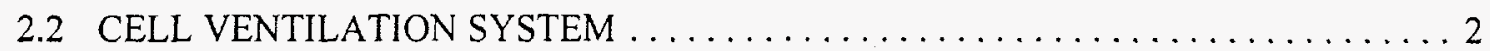

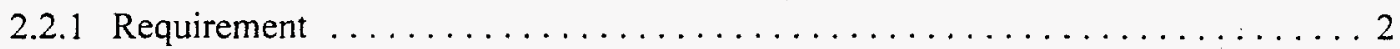

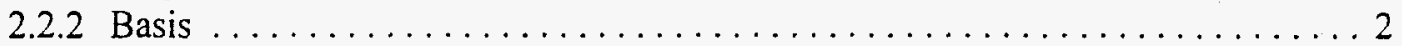

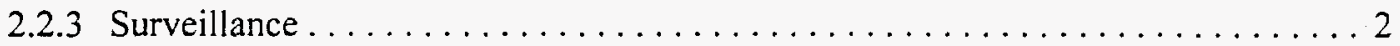

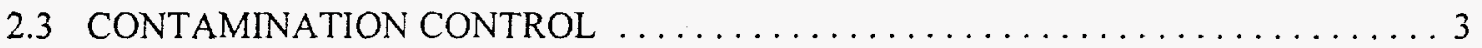

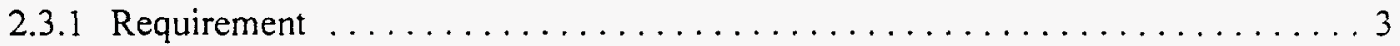

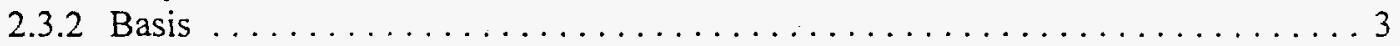

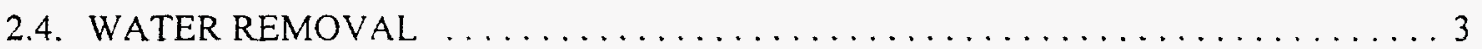

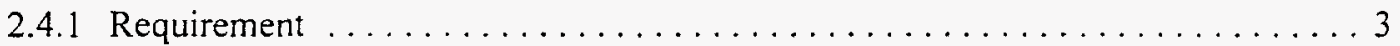

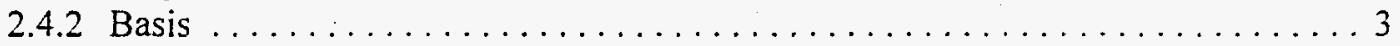

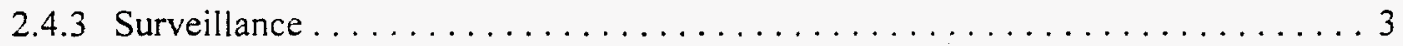

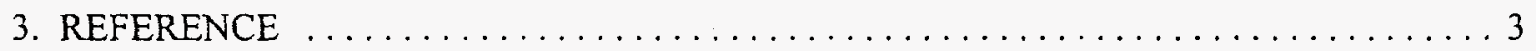




\section{INTRODUCTION}

The Limiting Conditions for the Oak Ridge Research Reactor (ORR), as detailed within this document, define the limitations, surveillances, and administrative guidelines necessary to ensure safe conditions at the facility. The ORR, Building 3042, had been classified as a "Generally-Accepted" in Hazard Screening Report, HS/3042/F/ORR/R1. In December 1994, Preliminary Hazard Screening ORNL/WM-RA/3042/PHS/R0 reclassified the ORR as a Radiological Facility.

Building 3042 contains an inactive and defueled $30 \mathrm{MW}$ research reactor, which operated from 1958 to 1987 . The reactor appurtenances and the stored waste in the pool remain highly activated. They are shielded by a 120,000-gal pool of demineralized water, which is located in the approximate center of the building and extends from the first floor to a parapet approximately $36 \mathrm{in}$. above the third floor pool access landing. The ORR is not occupied on a full-time basis; however, the first floor men's change room is used at shift change by the Office of Radiation Protection and Plant and Equipment Division personnel servicing the ORR and its ancillary facilities.

Noncompliance of this document is to be reported immediately to the Facility Manager (FM).

Note: It is not the intention of this document's requirements or any procedure generated by these requirements to limit emergency response actions and means that may be necessary to protect the safety and health of the general public, workers, or environment. Although it may supplement such emergency response actions or help baseline those actions, this document's primary purpose is to provide assistance in keeping the facility in a safe condition until destruction. It also is used as a reference in determining routine surveillance and maintenance activities taking place in the facilities. This document replaces WMRA-ERPS-3042-LCD, Rev. 1, "Limiting Conditions Document Oak Ridge Research Reactor (ORR)."

\section{LIMITING CONDITIONS FOR OPERATIONS}

\subsection{POOL WATER LEVEL}

\subsubsection{Requirement}

The pool make-up water is to be demineralized water. Resistivity and $\mathrm{pH}$ of the water will be monitored on a periodic basis to minimize corrosion of the aluminum liner in the pool. Radioactive contamination measurements in the water may be substituted for this after suitable correlation between it and water resistivity has been established and reported. If pool water level cannot be maintained at a level to prevent the Facility Radiation Monitoring System (FRMS) from alarming, the facility shall be evacuated of all nonessential personnel and access to the facility will not be permitted unless authorized by the FM, the Laboratory Shift Superintendent (LSS), and the Radiation Control Officer.

\subsubsection{Basis}

Maintaining the pool water level above the Reactor Pool grating provides assurance of adequate shielding from the activated components (Swanks et al. 1984). 


\subsubsection{Surveillance}

The pool water level shall be monitored by either (1) a low water level alarm associated with the Building 3042 Storage Pool Bleed and Feed System, which provides an alarm to the Waste Operations Control Center or the LSS Office, or (2) manual observation of the pool water level once per week.

The pool water level alarm system described in (1) shall be performance tested and any sensors calibrated, as applicable, on a schedule consistent with acceptable facility risks.

\subsubsection{Backup Radiation Monitoring System}

A backup to the pool water level detection system is the FRMS. The system consists of three monitron detectors. One monitron is located directly above each pool section (Reactor Pool, Center Storage Pool, and West Storage Pool).

\subsubsection{Basis}

The FRMS provides a reliable backup to the pool water level alarm. Should the pool water level alarm fail and the pool experience an uncontrolled loss of water, the monitrons would detect the elevated radiation levels caused by the loss of shielding around the activated components in the pool. Upon activation of the FRMS, a signal is sent to notify LSS of the elevated radiation levels in the building.

\subsubsection{Surveillance}

The monitrons and FRMS shall be tested and calibrated, as applicable, on an annual basis or at the request of the FM.

\subsection{CELL VENTILATION SYSTEM}

\subsubsection{Requirement}

Cell ventilation flow rate shall be maintained greater than $5000 \mathrm{ft}^{3} /$ min except during testing of the cell ventilation steam turbine fans.

\subsubsection{Basis}

This requirement defines conditions that ensure cell ventilation exhaust is adequate.

\subsubsection{Surveillance}

The building containment flow rate instruments and alarms shall be calibrated and performance tested on a periodic schedule consistent with acceptable facility risks. 


\subsection{CONTAMINATION CONTROL}

\subsubsection{Requirement}

Radiation and contamination surveys are performed at the request of the FM or designee.

\subsubsection{Basis}

The ORR is unoccupied with all entrance and work authorized by the FM or designee.

\subsection{WATER REMOVAL}

\subsubsection{Requirement}

The basement sump contains a high-level sump pump as backup to a lower level sump pump. The water level in the sump shall be monitored either by (1) a high water level alarm connected to the Waste Operations Control Center or LSS office, (2) a local alarm in the control room indicating that the high-level sump pump has been activated by high water, or (3) manual observation of the level as required. If both of the pumps fail at the same time, actions shall be taken to remove accumulated sump water before it runs onto the floor of the basement.

\subsubsection{Basis}

Maintaining a minimum of one operable sump pump in the basement sump is necessary to ensure groundwater in-leakage is adequately removed from the building to prevent flooding the sump and the resultant spread of contamination.

\subsubsection{Surveillance}

The sump water level alarm system instruments shall be calibrated and performance tested on a schedule consistent with acceptable facility risks.

\section{REFERENCE}

Swanks, J. H., McCord, R. J., and Corbett, B. L. May 1984. Operating Manual for the Oak Ridge Research Reactor, ORNL/TM-506/R1, Lockheed Martin Energy Systems, Inc., Oak Ridge, Tenn. 


\section{DISTRIBUTION}

1. S. Abercrombie

2. K. L. Allison

3. L. V. Asplund

4. C. A. Butler, Jr.

5. T. J. Cofer

6. D. L. Dillinger

7. M. D. Easton

8. J. E. Francis

9. S. A. Herron

10. T. M. Koepp

11. K. E. Long

12. C. E. Miles

13. M. J. Miller

14. P. T. Owen

15. D. J. Peterson

16. D. R. Pogue

17. L. B. Raulston

18. M. G. Ritchie

19. Central Research Library

20. File-EMEF DMC-RC 